\title{
PERBEDAAN LABA USAHA UNIT DAN NON PERFORMING LOAN DI BRI UNIT PORONG SEBELUM DAN SESUDAH BENCANA LUMPUR LAPINDO
}

\author{
Lulu Nurul Istanti \\ Fakultas Ekonomi Universitas Negeri Malang \\ J1. Surabaya No.6 Malang-65145. Telepon 0341-551312 pes.552888 \\ Website: http:/www.Malang.ac.id
}

\begin{abstract}
The aims of this study are to analyze the performance of the Bank Rakyat Indonesia Unit Porong before and after the lapindo hot mudflow disaster. The result of the study could be useful for those who are concerned with the profitability and liquidity of the bank.

The study involved Bank Rakyat Indonesia Unit Porong using purposive sample sampling method. The researcher also collected the monthly financial report of the sampling from February 2005 trough Augustus 2007

A number of statistical roles were used for data analysis including the data normality test and paired sample t-test. Result indicated that all variables are normally distributed. The paired sample t-test suggested that while significant difference exists in the Laba Usaha Unit between the two periods. There was no significant difference in the Non Performing Loans between the two periods.
\end{abstract}

Key words: laba usaha unit, non performing loan (NPL), even study

Menurut UNDP (1992:12), bencana adalah gangguan yang serius dari tidak berfungsinya satu masyarakat, yang menyebabkan kerugian-kerugian yang besar terhadap lingkungan, material, dan manusia, yang melebihi kemampuan dari masyarakat yang tertimpa bencana untuk menanggulangi dengan hanya menggunakan sumber-sumber daya masyarakat itu sendiri.

Bencana lumpur yang terjadi di Porong tanggal 29 Mei 2006 telah banyak berdampak pada sektor perekonomian masyarakat, baik yang terkena dampak secara langsung maupun secara tidak langsung. Dampak langsung dari bencana ini sangat dirasakan oleh masyarakat di tiga kecamatan di kabupaten Sidoarjo yaitu kecamatan Porong, Tanggulangin dan Jabon.

Akibat dampak dari bencana lumpur panas lapindo banyak Usaha Mikro Kecil dan Menengah (UMKM) yang harus menutup usaha karena lokasi usaha yang menjadi sumber kehidupan saat ini telah terendam lumpur, maupun terimbas dampak lumpur seperti para 
petani tambak yang tidak berani memulai usahanya karena sumber air bagi ikan telah tercampur dengan lumpur yang mengakibatkan hasil panen mereka tidak laku dijual.

Bencana lumpur panas lapindo mengakibatkan para pengusaha UMKM mengalami kesulitan untuk menjalankan operasional perusahaan sehingga perputaran uang perusahaan terhenti, padahal modal yang digunakan para pengusaha untuk menjalankan usaha pada umumnya berasal dari kredit uang diperoleh dari bank. Banyaknya UMKM yang berhenti beroperasi dan gulung tikar mengakibatkan banyak pekerja yang harus menganggur karena mereka tidak lagi bisa bekerja pada perusahaan yang selama ini dijadikan sandaran hidup. Besarnya nilai kredit yang tidak sehat dapat menyebabkan bank mengalami penurunan profitabilitas dan bahkan dapat mengakibatkan kesulitan likuiditas. Hal inilah yang sekarang sedang terjadi pada Bank Rakyat Indonesia Unit Porong. Porong merupakan daerah yang terkena dampak terbesar dari adanya bencana ini sehingga secara langsung sangat berpengaruh terhadap kondisi keuangan Bank Rakyat Indonesia Unit Porong.

Berdasarkan Undang-undang Republik Indonesia No. 10 tahun 1998 Tentang Perubahan atas Undang-undang No. 7 tahun 1992, pengertian bank adalah badan usaha yang menghimpun dana dari masyarakat dalam bentuk simpanan dan menyalurkannya kepada masyarakat dalam bentuk kredit dan atau bentuk-bentuk lainnya dalam rangka meningkatkan taraf hidup orang banyak.

Menurut Nawawi (2005:6) PT. Bank Rakyat Indonesia (Persero) Tbk merupakan salah satu bank terbesar di Indonesia yang memfokuskan diri pada pembiayaan mikro. Hampir 80\% kredit BRI ada di segmen UMKM. Dwi Asih Surjandari (2004) dalam penelitiannya menyatakan bahwa "meskipun PT. BRI (Persero) melayani nasabah miskin, PT. BRI (Persero) tetap dapat mencapai financial sustainability". Sedangkan untuk tingkat kredit macet di BRI sendiri sangat rendah, hal ini dikarenakan fokus inti BRI adalah pembiayaan mikro, UMKM dan kredit konsumen berpenghasilan rendah sampai menengah (Nawawi, 2005:6). Akan tetapi apabila hal itu terus menerus dibiarkan tanpa adanya penanganan khusus, maka tunggakan yang terjadi kemungkinan akan meningkat dan akibatnya aktivitas bank menjadi terganggu. Untuk itu, dalam upaya menekan seminimal mungkin terjadinya tunggakan, maka BRI harus melakukan pengelolaan yang profesional terhadap kredit yang disalurkan sehingga dapat meningkatkan keuntungan BRI. 
Profitabilitas adalah kemampuan perusahaan untuk menghasilkan keuntungan sedangkan mendapatkan keuntungan adalah tujuan utama suatu perusahaan tersebut didirikan, dan dari keuntungan yang diperoleh tersebut bisa digunakan untuk mengembangkan perusahaan, dalam penelitian ini yang digunakan sebagai ukuran profitabilitas adalah Laba Usaha Unit. Likuiditas adalah kesanggupan bank dalam menyediakan alat-alat lancar guna membayar kembali dana titipan yang telah jatuh tempo dan memberi pinjaman (loan) kepada masyarakat yang membutuhkan. Dalam penelitian ini yang digunakan untuk mengukur tingkat likuiditas adalah Non Performing Loan (NPL), yaitu perbandingan antara kredit bermasalah dengan total kredit di suatu bank. Yang masuk dalam kategori kurang lancar (KL), diragukan (D), macet (M) dengan total kredit yang disalurkan di suatu bank. Oleh karena itu profitabilitas dan likuiditas merupakan hal yang sangat penting bagi kelangsungan perusahaan perbankan.

Berdasarkan latar belakang diatas, maka penelitian ini bertujuan untuk mengetahui bagaimana kondisi Laba Usaha Unit dan Non Performing Loan (NPL) BRI Unit Porong sejak terjadi bencana lumpur panas lapindo, dan untuk mengetahui apakah ada perbedaan Laba Usaha Unit di BRI Unit Porong sebelum dan sesudah terjadi bencana lumpur panas lapindo.

\section{BENCANA}

Bencana adalah gangguan yang serius dari tidak berfungsinya satu masyarakat, yang menyebabkan kerugian-kerugian yang besar terhadap lingkungan, material, dan manusia, yang melebihi kemampuan dari masyarakat yang tertimpa bencana untuk menanggulangi dengan hanya menggunakan sumber-sumber daya masyarakat itu sendiri (UNDP,1992:12).

Bencana lumpur panas lapindo dimulai pada tanggal 29 Mei 2006. Peristiwa ini menjadi suatu bencana ketika banjir lumpur panas yang awalnya hanya menggenangi areal persawahan mulai menggenangi pemukiman penduduk dan kawasan industri. Hal ini terjadi karena volume lumpur yang awalnya diperkirakan sekitar 5.000 hingga 50 ribu meter kubik perhari kini telah mengalami peningkatan volume semburan menjadi lebih dari 125 ribu meter kubik perhari. Akibatnya, semburan lumpur ini membawa dampak negatif yang luar biasa bagi masyarakat sekitar maupun bagi aktivitas perekonomian di Jawa Timur.

Lumpur panas dan gas yang keluar mengandung bahan beracun dan berbahaya bagi kesehatan masyarakat seperti fenol, H2S, NO2, dan NH3. Selain itu semburan lumpur ini 
mengakibatkan genangan setinggi 16 meter pada pemukiman hingga menenggelamkan 7 desa. Saat ini total warga yang dievakuasi lebih dari 24.900 jiwa dari $6.751 \mathrm{KK}, 1044 \mathrm{KK}$ atau 3.730 jiwa diantaranya hidup di pengungsian di Pasar Baru Porong, rumah/tempat tinggal yang rusak sebanyak 10.426 unit, areal pertanian dan perkebunan rusak hingga lebih dari 379 ha, lebih dari 31 unit pabrik yang tergenang menghentikan aktivitas produksi dan merumahkan lebih dari 3.873 orang, tidak berfungsinya 33 unit sarana pendidikan, kerusakan lingkungan wilayah yang tergenang, rusaknya sarana dan prasarana infrastruktur (jaringan listrik, telepon, jalan tol), terendamnya rel kereta api sehingga sering kali terjadi pembatalan jadwal keberangkatan kereta, terhambatnya ruas jalan Malang-Surabaya yang berakibat pula terhadap aktivitas produksi di kawasan Ngoro (Mojokerto) dan Pasuruan yang selama ini merupakan kawasan industri utama di Jawa Timur

\section{BANK RAKYAT INDONESIA}

Bank merupakan sebuah lembaga keuangan yang mempunyai peranan penting bagi jalannya roda perekonomian di negara kita. Menurut Santoso (1997:1) pengertian bank adalah industri yang bergerak di bidang kepercayaan yang dalam hal ini adalah sebagai media perantara keuangan (financial intermediary) antar debitur dan kreditur dana. Sedangkan berdasarkan Undang-undang No. 10 tahun 1998 tentang perbankan, pengertian bank adalah badan usaha yang menghimpun dana dari masyarakat dalam bentuk simpanan dan menyalurkannya kepada masyarakat dalam bentuk kredit dan atau bentuk-bentuk lainnya dalam rangka meningkatkan taraf hidup orang banyak.

Kasmir (2002:11) mengemukakan pengertian bank sebagai lembaga keuangan atau perusahaan yang bergerak di bidang keuangan, yang artinya semua aktivitas perbankan selalu berkaitan dalam bidang keuangan. Sedangkan Sinungan (1991:160) mendefinisikan bahwa "bank adalah suatu badan usaha yang kegiatan utamanya menerima simpanan dari masyarakat dan atau pihak lainnya, kemudian mengalokasikannya kembali untuk memperoleh keuntungan dan menyediakan jasa-jasa dalam lalu lintas pembayaran". Dari uraian di atas dapat dijelaskan bahwa bank merupakan perusahaan yang bergerak di bidang keuangan, artinya usaha perbankan selalu berkaitan dengan masalah keuangan. Jadi dapat disimpulkan bahwa usaha perbankan meliputi tiga kegiatan utama yaitu, menghimpun dana, menyalurkan dana dan memberikan jasa bank lainnya. 
PT. Bank Rakyat Indonesia (Persero) didirikan tahun 1895 sampai sekarang memfokuskan diri pada pelayanan masyarakat kecil, hal itu terbukti dari adanya pemberian fasilitas kredit kepada golongan pengusaha kecil, dan menengah. Sampai 31 Maret 2007 lalu, BRI telah menyalurkan kredit kepada para pengusaha UMKM Rp 79,17 triliun atau 86,94\% dari total portofolio kredit BRI Rp 91,06 triliun dan saat ini BRI merupakan Bank BUMN penyumbang APBN terbesar.

Seiring dengan perkembangan dunia perbankan yang semakin pesat, maka sampai saat ini Bank Rakyat Indonesia mempunyai unit kerja yang berjumlah 4447 buah, yang terdiri dari 1 Kantor Pusat BRI (Kanpus), 13 Kantor Wilayah (Kanwil), 325 Kantor Cabang (Kanca), 64 Kantor Cabang Pembantu (Kancapem), 1 Kantor Cabang Khusus(KCK), 1 New York Agency, 1 Caymand Island Agency, 1 Kantor Perwakilan Hongkong, 40 Kantor Kas Bayar, 6 Kantor Mobil Bank, 193 Payment point, 3705 BRI Unit dan 357 Pos Pelayan Desa (PPD).

\section{LABA USAHA UNIT}

Mendapatkan keuntungan adalah tujuan suatu perusahaan didirikan, karena dari keuntungan tersebut akan dapat digunakan untuk mengembangkan usaha yang telah didirikan. Profitabilitas itu sendiri menurut Munawir (2000:86) adalah kemampuan perusahaan untuk menghasilkan keuntungan. Dan untuk mengukurnya dapat digunakan berbagai rasiorasio yang tentu saja berhubungan dengan profitabilitas.

Menurut Suhardjono (2003: 418) rasio profitabilitas adalah rasio yang digunakan untuk mengetahui kemampuan perusahaan dalam menghasilkan keuntungan dihubungkan dengan penjualan, aktiva, dan modal sendiri. Sehingga dapat disimpulkan bahwa rasio profitabilitas adalah rasio yang dapat digunakan untuk mengukur tingkat keuntungan suatu perusahaan jika dihubungkan dengan penjualan, aktiva dan modal sendiri. Dalam penelitian ini yang digunakan sebagai ukuran untuk mengukur tingkat profitabilitas adalah Laba Usaha Unit yaitu pendapatan usaha unit yang meliputi pendapatan bunga dan pendapatan operasional lainya dikurangi seluruh beban usaha dan biaya yang ada.

Menurut Suhardjono (2003:3) menyatakan bahwa "kredit merupakan tulang punggung bagi kelangsungan hidup usaha bank dan kredit juga sebagai penyebab utama kebangkrutan sebuah bank, sehingga bagian terbesar dari aset bank berupa kredit, begitu juga halnya dengan pendapatan bank sebagian besar berasal dari pendapatan bunga kredit". Sedangkan menurut hasil penelitian Dwi Asih Suryandari (2004:30) menyatakan bahwa "dengan adanya pemberian 
kredit kepada nasabah mikro, BRI tetap dapat mencapai return yang baik. Selain itu Rudjito (2005:8) mengatakan bahwa "naiknya laba BRI didorong dari peningkatan ekspansi kredit". Sehingga dapat disimpulkan bahwa besarnya pinjaman atau kredit yang disalurkan dapat mempengaruhi laba.

Adanya pengaruh tunggakan kredit terhadap laba menurut R. Tjiptoadinugroho dalam Dyah Noor (2001:25) menyatakan "bahwa pengaruh dari tunggakan kredit adalah apabila terdapat jumlah tunggakan kredit yang terus menerus meningkat maka akan berakibat menurunnya tingkat keuntungan perusahaan dan berpengaruh terhadap menurunnya sumber modal itu sendiri dan begitu pula sebaliknya". Sedangkan menurut hasil penelitian Dyah Noor (2001:67) juga menyatakan bahwa bila tunggakan kredit naik maka laba akan turun begitu pula sebaliknya jika tunggakan kredit turun maka laba akan naik. Sehingga dapat disimpulkan bahwa semakin besar tunggakan kredit maka semakin kecil laba usaha dan sebaliknya semakin kecil tunggakan kredit yang ada semakin besar laba yang diperoleh.

Sehingga dengan adanya kinerja kredit yang baik, maka hal itu akan mempengaruhi tingkat profitabilitas suatu perusahaan. Dalam hal ini adalah adanya kinerja kredit mikro yang baik, maka hal itu akan mempengaruhi tingkat profitabilitas yaitu laba di Bank Rakyat Indonesia Unit Porong.

\section{NON PERFORMING LOAN (NPL)}

Untuk menjaga kondisi likuiditasnya perusahaan sebaiknya menyimpan kekayaanya dalam bentuk instrumen keuangan karena instrumen keuangan dapat dikonversi menjadi kas atau uang tunai di pasar keuangan dengan risiko yang kecil.

Pengelolaan likuiditas merupakan masalah yang sangat kompleks dalam kegiatan operasi perbankan, sulitnya pengelolaan likuiditas tersebut disebabkan dana yang dikelola bank sebagian besar adalah dana masyarakat yang sifatnya jangka pendek dan dapat ditarik sewaktu-waktu. Oleh karena itu bank harus memperhatikan seakurat mungkin kebutuhan likuiditas untuk suatu jangka tertentu. Perkiraan kebutuhan likuiditas tersebut sangat dipengaruhi oleh perilaku penilaian nasabah, sifat dan jenis sumber dana yang dikelola bank.

Menurut Joseph E. Burns dalam Siamat (2005:336) likuiditas bank berkaitan dengan kemampuan suatu bank untuk menghimpun sejumlah tertentu dana dengan biaya tertentu dan dalam jangka waktu tertentu. Oliver dan Wood mendefinisikan likuiditas adalah kemampuan bank untuk memenuhi semua penarikan dana dari nasabah deposan, kewajiban yang telah 
jatuh tempo, dan memenuhi permintaan kredit tanpa penundaan. Sedangkan Glavin berpendapat bahwa likuiditas berarti memiliki sumber dana yang cukup tersedia untuk memenuhi seluruh kewajiban.

Sumber utama kebutuhan likuiditas bank berasal dari adanya kebutuhan yang digunakan untuk memenuhi yaitu; ketentuan likuiditas wajib (reverse requirement) atau cash ratio, saldo rekening minimum pada bank koresponden, penarikan simpanan pada operasional bank sehari-hari dan permintaan kredit dari masyarakat.

Berdasarkan pada konsep dasar likuiditas dan pemenuhan likuiditas bank, maka suatu bank dianggap likuid apabila memiliki jumlah likuiditas sama dengan jumlah kebutuhan likuiditasnya, memiliki likuiditas kurang dari kebutuhan tetapi bank mempunyai surat-surat berharga yang dapat dialihkan dengan segera menjadi kas dan memiliki kemampuan untuk memperoleh likuiditas dengan cara menciptakan uang.

Menurut Fatchudin (2004:11) untuk menilai kinerja kredit mikro (Kupedes) dapat diukur dari beberapa hal sebagai berikut :

a. Out Standing Kupedes yaitu besarnya kredit yang disalurkan oleh suatu bank.

b. Tunggakan kredit yaitu pinjaman yang tidak dapat dilunasi oleh nasabah pada saat perjanjian berakhir.

c. Non Performing Loan (NPL) perbandingan antara kredit bermasalah dengan total kredit yang disalurkan oleh suatu bank.

Analisis untuk menilai tingkat keberhasilan bank pada periode tertentu berdasarkan rencana kerja, laporan realisasi rencana kerja dan laporan berkala bank, sedangkan untuk mengukur kinerja kredit hal itu dapat dilihat dari jumlah kredit yang disalurkan, jumlah tunggakan yang terjadi dan tingkat Non Performing Loan (NPL) dari suatu bank.

Menurut Siamat (2005:337) pada dasarnya bank yang memiliki tingkat laba yang tinggi dapat menghindari masalah kesulitan likuiditas. Sedangkan Panji (2005) menyatakan "bahwa semakin tinggi NPL suatu bank menunjukkan jumlah kredit bermasalah tersebut dalam jumlah yang relatif besar terhadap kredit yang disalurkan". Sehingga dapat disimpulkan bahwa dengan semakin besarnya tunggakan kredit yang terjadi akan menyebabkan nilai Non Performing Loan meningkat. Nilai Non Performing yang semakin besar akan menyebabkan menurun laba dan akan mengakibatkan bank mengalami kesulitan likuiditas. Dengan kata lain 
besar kecilnya Non Performing Loan akan berpengaruh terhadap laba perusahaan yang selanjutnya akan berdampak pada tingkat likuiditas suatu bank.

\section{Event Study (Studi Peristiwa)}

Event study adalah suatu pengamatan mengenai pergerakan harga saham di pasar modal untuk mengetahui apakah ada abnormal return yang diperoleh pemegang saham akibat dari suatu peristiwa tertentu (Peterson dalam Suryawijaya, 1998). Menurut Jogiyanto (2000) event study merupakan studi yang mempelajari reaksi pasar modal terhadap peristiwa (event) yang informasinya dipublikasikan sebagai pengumuman dan dapat juga digunakan untuk menguji efisiensi pasar bentuk setengah kuat. Dari pengertian di atas event study berguna untuk menguji efisiensi pasar modal setengah kuat, apakah muatan inforamasi sebuah peristiwa berpengaruh atau terefleksi didalam pasar modal secara benar.

\section{METODE}

Variabel yang digunakan dalam penelitian ini adalah Laba Usaha Unit dan Non Performing Loan (NPL) di BRI Unit Porong. Penelitian ini merupakan penelitian dengan pendekatan kuantitatif, yaitu mengumpulkan, mengolah, menyederhanakan, menyajikan dan menganalisa data agar dapat memberikan gambaran yang teratur tentang suatu peristiwa dengan observasi yang dinyatakan dengan angka-angka.

Penelitian ini membandingkan Laba Usaha Unit dan Non Performing Loan (NPL) di BRI Unit Porong sebelum dan sesudah bencana lumpur lapindo yang terjadi tanggal 29 Mei 2006. Periode penelitian dilakukan dari bulan Februari tahun 2005 sampai dengan bulan Agustus 2007, yang digambarkan sebagai berikut:

Februari 2005

29 Mei 2006

Agustus 2007

Populasi penelitian adalah Laporan Keuangan BRI unit Porong, sedangkan sampel penelitian yang digunakan adalah Laporan Keuangan BRI Unit Porong dari bulan Februari tahun 2005 sampai dengan bulan Agustus 2007.

Data penelitian diperoleh dari dua studi, yang pertama adalah studi literatur yang dilakukan untuk memberi gambaran teoritis yang mendukung kerangka berfikir dan hipotetis. 
Yang kedua adalah studi lapangan yang bertujuan untuk mendapatkan data yang berguna untuk menguji dan menganalisis perbedaan Laba Usaha Unit dan Non Performing Loan (NPL) di BRI Unit Porong sebelum dan sesudah bencana lumpur lapindo yang terjadi tanggal 29 Mei 2006.

Penelitian ini menggunakan data sekunder. Data sekunder adalah data yang diperoleh tidak dari sumbernya langsung melainkan sudah dikumpulkan oleh pihak lain yang sudah diolah dan biasanya dalam bentuk publikasi dan jurnal. Data skunder yang digunakan dalam penelitian ini adalah Laporan Keuangan yang dikeluarkan oleh BRI Unit Porong.

Hipotesis dalam penelitian ini adalah:

1. Diduga terdapat perbedaan Laba Usaha Unit di BRI Unit Porong periode sebelum dengan periode sesudah terjadinya bencana lumpur panas lapindo

2. Diduga terdapat perbedaan Non Performing Loan (NPL) di BRI Unit Porong periode sebelum dengan periode sesudah terjadinya bencana lumpur panas lapindo

Pengujian statistik dilakukan dengan menggunakan program komputer SPSS for Windows Vertion 13.0, untuk mengetahui data itu berdistribusi normal atau tidak maka dilakukan uji normalitas terlebih dahulu. Apabila data berdistribusi normal digunakan teknik statistik uji rata-rata dari dua kelompok sampel yang berpasangan (paired Two Sample For Means test). Uji t digunakan jika dilakukan analisis dua sampel berpasangan dengan taraf signifikan sebesar 5\% $(\alpha=0,05)$. Apabila data berdistribusi tidak normal digunakan teknik analisis statistik non parametrik Wilcoxon Signed Ranks Test dengan taraf signifikan sebesar 5\% $(\alpha=0,05)$.

\section{HASIL}

\section{Kondisi Laba Usaha Unit di BRI Unit Porong}

Laba usaha unit adalah laba yang diperoleh dari pendapatan usaha unit yang meliputi pendapatan bunga kredit serta pendapatan usaha lainnya dikurangi seluruh biaya-biaya yang dikeluarkan unit, Berikut adalah Tabel 1 yang menunjukkan perbandingan tingkat laba usaha unit yang diperoleh BRI Unit Porong selama periode sebelum dan sesudah bencana lumpur panas lapindo.

\section{Tabel 1}

Kondisi Laba Usaha unit di BRI Unit Porong Sebelum dan Sesudah

Bencana Lumpur Panas Lapindo 


\begin{tabular}{|c|r|r|}
\hline Laba Usaha Unit & Sebelum (Rupiah) & \multicolumn{1}{c|}{ Sesudah (Rupiah) } \\
\hline Rata-rata & 134.500 .866 .67 & $-21.539 .800,00$ \\
\hline Jumlah & $2.017 .513 .000,00$ & $-323.097 .000,00$ \\
\hline
\end{tabular}

(Sumber: data diolah)

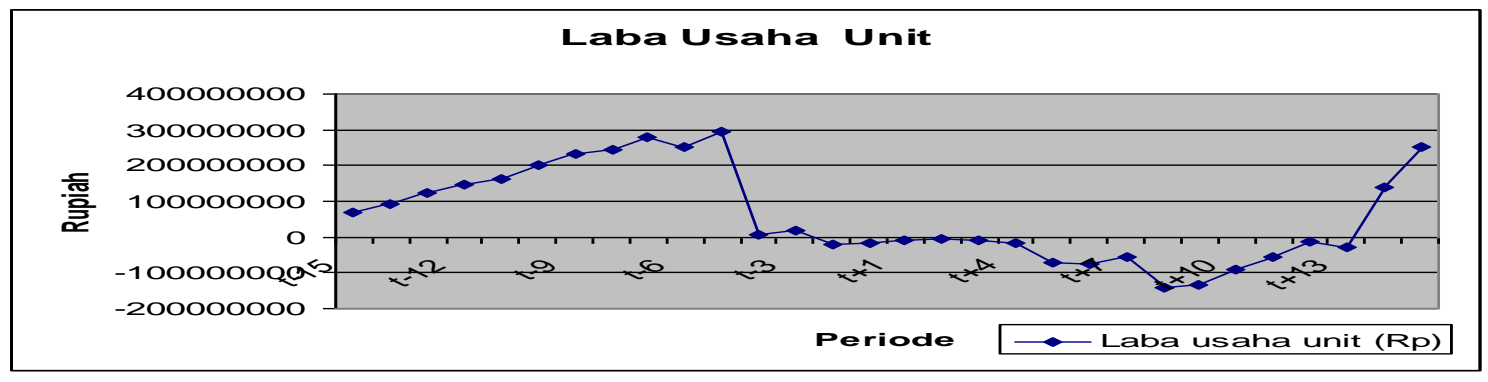

Gambar 1

Grafik Laba Usaha Unit

Berdasarkan Tabel 1 dapat diperoleh data bahwa laba usaha unit Bank Rakyat Indonesia Unit Porong mengalami penurunan yang sangat besar, rata-rata laba usaha unit BRI Unit Porong mengalami penurunan yang sangat besar yaitu dari Rp134.500.866.67 pada periode sebelum menjadi minus Rp21.539.800,00 (mengalami kerugian) atau mengalami penurunan sebesar Rp156.040.666,67.

Secara keseluruhan laba usaha unit yang diperoleh mengalami penurunan dari Rp2.017.513.000,00.selama periode sebelum menjadi mengalami kerugian yaitu sebesar Rp323.097.000,00 selama periode sesudah. Secara keseluruhan laba usaha unit BRI Unit Porong mengalami penurunan sebesar Rp2.340.600.000,00.

\section{Kondisi Non Performing Loan (NPL) di BRI Unit Porong}

Untuk mengetahui nilai Non Performing Loan (NPL) di BRI Unit Porong dapat dilakukan dengan menganalisa data yang ada yaitu dengan membandingkan jumlah Sisa pokok tunggakan kredit terhadap jumlah kredit yang disalurkan, sisa pokok tunggakan kredit adalah tunggakan yang terjadi pada bulan berjalan dikurangi biaya bunga yang dibebankan. 


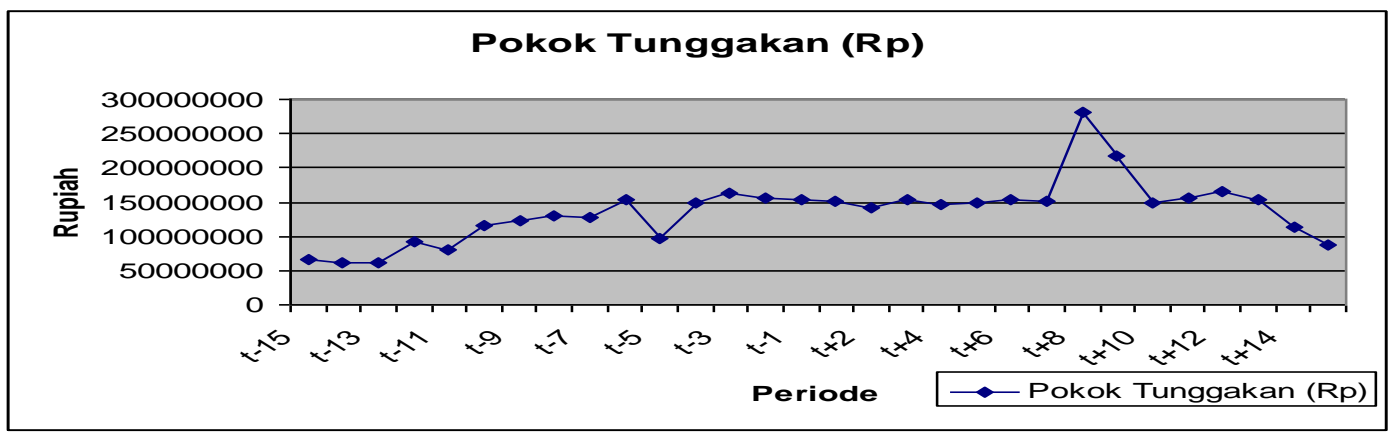

Gambar 2

Grafik Pokok Tunggakan

Berdasarkan grafik diatas dapat diketahui bahwa pada periode sesudah bencana lumpur panas lapindo tunggakan yang terjadi cenderung sedikit mengalami peningkatan walaupun jumlahnya tidak terlampau besar. Kondisi ini dapat dilihat dengan membandingkan rata-rata dan jumlah pokok tunggakan pada periode sebelum dan sesudah bencana lumpur panas lapindo. Walaupun bencana lumpur panas lapindo mengakibatkan kredit macet yang jumlahnya milyaran rupiah namun jumlah tunggakan kredit yang ada pada BRI Unit porong tidak begitu terpengaruh.

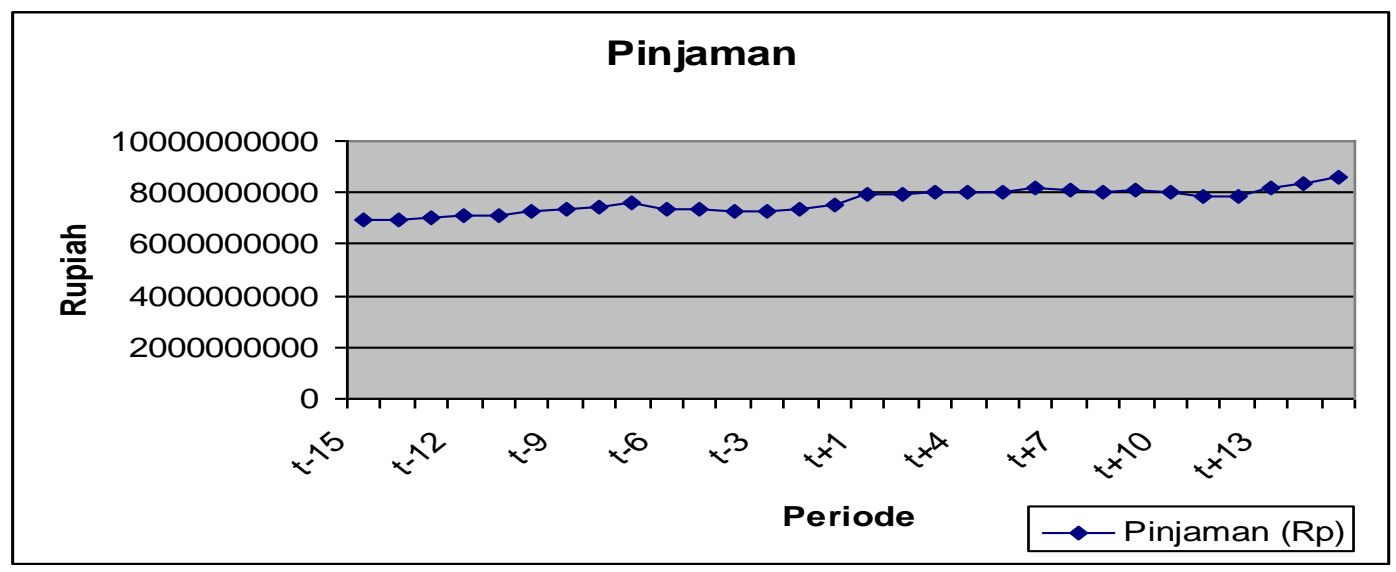

Gambar 3

Grafik Pinjaman Tersalur

Berdasarkan Grafik 3 dapat diketahui bahwa walaupun wilayah kerja BRI unit porong telah berkurang karena 4 desa wilayah kerjanya terendam lumpur jumlah pinjaman yang disalurkan BRI Unit Porong kepada masyarakat dalam bentuk kredit mikro (KUPEDES) pada periode sebelum dan sesudah mengalami siklus yang sama dan cenderung mengalami peningkatan jumlah kupedes yang disalurkan Besarnya persentase NPL dapat dilihat pada Tabel 2 sebagai berikut: 
Tabel 2

Kondisi Laba Tabungan di BRI Unit Porong Sebelum dan Sesudah

Bencana Lumpur Panas Lapindo

\begin{tabular}{|c|r|r|}
\hline NPL & Sebelum (Persen) & \multicolumn{2}{|c|}{ Sesudah (Persen) } \\
\hline Rata-rata & 1.57 & 1.96 \\
\hline Jumlah & 23.67 & 29.41 \\
\hline
\end{tabular}

(Sumber: data diolah)

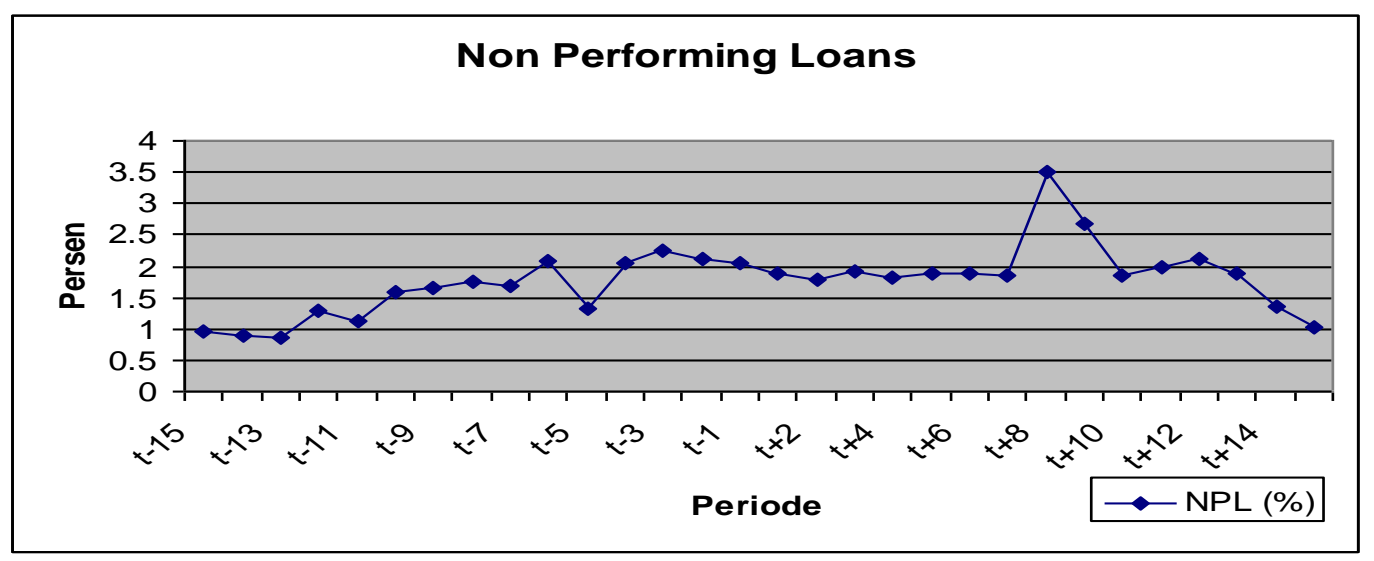

Gambar 4

Grafik Persentase NPL

Berdasarkan Tabel 2 dapat diperoleh data bahwa Non Performing Loan (NPL) Bank Rakyat Indonesia Unit Porong mengalami sedikit peningkatan, pada rata-rata Non Performing Loan di BRI Unit Porong mengalami peningkatan yaitu dari 1.578 \% pada periode sebelum menjadi $1,960 \%$ atau mengalami sedikit peningkatan yaitu sebesar $0.382 \%$

Secara keseluruhan nilai Non Performing Loan di BRI Unit Porong mengalami peningkatan dari 23.67 \% selama periode sebelum menjadi $29.41 \%$ selama periode sesudah. Secara keseluruhan nilai Non Performing Loan di BRI Unit Porong mengalami peningkatan sebesar $5.74 \%$

\section{Pengujian Hipotesis Pertama}

Setelah dilakukan pengujian normalitas maka dilakukan pengujian hipotesis yaitu untuk mengetahui apakah bencana lumpur lapindo berpengaruh terhadap Laba Usaha Unit di BRI Unit Porong. Pengujian hipotesis dilakukan dengan menggunakan program SPSS yaitu statistik parametik "Paired Two Sample For Mean Test" (uji t), semua variabel di uji dengan 
menggunakan uji t karena semuanya berdistribusi normal. Berikut hasil pengujian hipotesis pertama:

Tabel 2

Hasil Uji Statistik t-Test Paired Two Sample for Means Laba Usaha Unit

BRI Unit Porong Sebelum dan Sesudah Bencana Lumpur Panas Lapindo

\begin{tabular}{|c|c|c|c|}
\hline & t hitung & Signifikansi & Hasil \\
\hline Laba Usaha Unit & 3,125 & 0,007 & Ho Ditolak \\
\hline
\end{tabular}

(Sumber: data diolah)

Uji statistik pada laba usaha unit Bank Rakyat Indonesia Unit Porong menyimpulkan bahwa Ho Ditolak. Hal tersebut dibuktikan dengan nilai thitung $(3,125)$ lebih besar dari tabel $(2,145)$ dan nilai signifikansi (2-tailed) lebih kecil dari 0,05 yaitu 0,007 seperti tampak pada tabel 2. Ditolaknya Ho berarti bahwa terdapat perbedaan yang signifikan Laba Usaha Unit BRI Unit Porong sebelum dan sesudah bencana lumpur panas lapindo.

\section{Pengujian Hipotesis Kedua}

Setelah dilakukan pengujian normalitas maka dilakukan pengujian hipotesis yaitu untuk mengetahui apakah bencana lumpur lapindo berpengaruh terhadap Non Performing Loan di BRI Unit Porong. Pengujian hipotesis dilakukan dengan menggunakan program SPSS yaitu statistik parametik "Paired Two Sample For Mean Test" (uji t), semua variabel di uji dengan menggunakan uji $t$ karena semuanya berdistribusi normal. Berikut hasil pengujian hipotesiskedua:

Tabel 3

Hasil Uji Statistik t-Test Paired Two Sample for Means Non Performing Loan BRI Unit Porong Sebelum dan Sesudah Bencana Lumpur Panas Lapindo

\begin{tabular}{|c|c|c|c|}
\hline & t hitung & Signifikansi & Hasil \\
\hline NPL & $-1,986$ & 0,067 & Ho Diterima \\
\hline
\end{tabular}

(Sumber: data diolah)

Uji statistik pada Pinjaman Bank Rakyat Indonesia Unit Porong menyimpulkan bahwa Ho diterima. Hal tersebut dibuktikan dengan nilai $t$ hitung $(-1,986)$ lebih besar dari $t$ tabel $(2,145)$ dan nilai signifikansi (2-tailed) lebih besar dari 0,05 yaitu 0,067 seperti tampak pada tabel 3. Diterimanya Ho berarti bahwa tidak terdapat perbedaan yang signifikan pada Non Performing Loan Bank Rakyat Indonesia sebelum dan sesudah bencana lumpur panas lapindo. 


\section{PEMBAHASAN}

\section{Kondisi Laba Usaha Unit dan Non Performing Loan di BRI Unit Porong}

Berdasarkan perhitungan, diketahui bahwa nilai laba usaha unit 15 bulan sesudah bencana lumpur panas lapindo mengalami penurunan yang cukup besar dibandingkan dengan periode 15 bulan sebelumnya. Bencana lumpur panas lapindo menyebabkan peningkatan jumlah kredit bermasalah yang cukup besar sehingga laba usaha unit periode sebelum dan sesudah bencana lumpur panas lapindo mengalami penurunan, kondisi ini menunjukkan bahwa pendapatan usaha unit yang meliputi pendapatan bunga dan pendapatan operasional lainnya setelah dikurangi seluruh beban usaha dan biaya yang ada mengalami penurunan drastis, dan bahkan mencapai angka minus atau mengalami kerugian.

Berkurangnya empat desa wilayah kerjanya, dan jumlah kredit bermasalah yang cukup besar, berdampak pada penurunan jumlah kredit yang disalurkan oleh unit. Di sisi lain jumlah tabungan masyarakat yang tersimpan di BRI mengalami peningkatan karena banyak bankbank lain yang menutup usaha atau memindahkan lokasi usaha sehingga banyak terdapat nasabah baru, kondisi ini menyebabkan dana pihak ketiga yang disetor ke cabang oleh unit mengalami peningkatan sehingga perolehan laba tabungan mengalami peningkatan.

\section{Kondisi Non Performing Loan di BRI Unit Porong}

Likuiditas merupakan kemampuan perusahaan untuk memenuhi kewajiban finansial jangka pendek tepat pada waktunya. Salah satu ukuran likuiditas yang digunakan dapat digunakan adalah Non Performing Loan (NPL)

Non Performing Loan (NPL) adalah perbandingan antara kredit bermasalah dengan total kredit yang disalurkan suatu bank. Yang masuk dalam NPL adalah kredit dalam kategori kurang lancar (KL), diragukan (D), macet (M) yang disalurkan di suatu bank.

Berdasarkan perhitungan Non Performing Loan (NPL) Bank Rakyat Indonesia Unit Porong, diketahui bahwa nilai NPL 15 bulan sesudah bencana lumpur panas lapindo mengalami peningkatan dibandingkan 15 bulan sebelumnya. Hal ini menunjukkan bahwa kondisi likuiditas BRI Unit Porong sesudah bencana lumpur panas lapindo mengalami penurunan. Namun penurunan likuiditas yang terjadi di BRI Unit Porong masih dalam kondisi yang wajar dan tidak menyebabkan BRI Unit Porong masuk dalam kategori bank yang tidak sehat. Karena berdasarkan ketentuan dari Bank Indonesia yang menetapkan batas maksimal 
untuk NPL adalah $5 \%$, maka untuk mengukur kinerja NPL digunakan beberapa kategori, yaitu:

a. $0-2,5 \%$ yaitu sangat sehat

b. $2,5-5 \%$ yaitu sehat

c. $>5 \%$ yaitu tidak sehat

Sedangkan kondisi Non Performing Loan di BRI Unit Porong masih dalam kondisi sehat dengan nilai Non Performing Loan tertinggi sesudah bencana lumpur panas lapindo sebesar 3.49 \% dan nilai rata-rata Non Performing Loan pada periode sesudah bencana lumpur panas lapindo sebesar $1,96 \%$. Hal ini sedikit mengalami peningkatan apabila dibandingkan dengan periode sebelum yang memiliki rata-rata sebesar $1,578 \%$.

Perbedaan Laba Usaha Unit di BRI Unit Porong Sebelum dan Sesudah Bencana Lumpur Panas Lapindo

Pengujian hipotesis pada Laba usaha unit menyimpulkan bahwa terdapat perbedaan yang signifikan pada laba usaha unit Bank Rakyat Indonesia Unit Porong periode sebelum dan sesudah bencana lumpur panas lapindo. Hal ini menunjukkan bahwa bencana lumpur panas lapindo mengakibatkan perubahan yang cukup berarti pada nilai laba usaha unit, yang terlihat dari menurunnya nilai laba usaha unit.

Adanya perbedaan yang cukup signifikan tersebut dikarenakan meningkatnya kredit yang bermasalah, adanya kredit macet yang cukup besar mengakibatkan bank mengalami kehilangan pendapatan bunga dari kredit yang bermasalah tersebut. Selain itu bank harus mencadangkan asetnya sebesar 100\% nilai kredit macet agar besarnya kredit bermasalah tidak mempengaruhi secara langsung tunggakan kredit. Akan tetapi bank tetap mengalami penurunan laba yang cukup besar karena harus mencadangkan asetnya dan kehilangan pendapatan bunga. Kondisi ini didukung oleh penelitian yang dilakukan oleh Dyah Noor (2001:67) yang menyatakan bahwa bila tunggakan kredit naik maka laba akan turun begitu pula sebaliknya jika tunggakan kredit turun maka laba akan naik. Serta berpengaruh terhadap menurunnya sumber modal itu sendiri dan begitu pula sebaliknya.

Perbedaan Non Performing Loan (NPL) di BRI Unit Porong Sebelum dan Sesudah Bencana Lumpur Panas Lapindo

Pengujian hipotesis pada Non Performing Loan (NPL) menyimpulkan bahwa tidak terdapat perbedaan yang signifikan pada Non Performing Loan (NPL) di BRI Unit Porong 
periode sebelum dan sesudah bencana lumpur panas lapindo. Walaupun ada peningkatan nilai Non Performing Loan di BRI Unit Porong. Hal ini dapat diartikan bahwa bencana lumpur panas lapindo membawa tidak berpengaruh terhadap kondisi Non Performing Loan di BRI Unit Porong.

Tidak adanya perbedaan yang cukup signifikan ini terjadi karena bencana lumpur panas lapindo menyebabkan hampir seluruh kredit yang disalurkan di empat desa yang terendam lumpur masuk dalam kategori kredit macet. Untuk menjaga agar kondisi ini tidak menyebabkan likuiditas BRI Unit Porong terganggu maka terhadap kredit-kredit tersebut dilakukan percepatan masuk dalam Daftar Hitam yang untuk selanjutnya dilakukan restrukturisasi kredit dan pembinaan sehingga kredit tersebut bisa diselesaikan oleh debitur. Kebijakan ini diambil karena Porong masuk dalam kondisi force majeur atau bencana, dengan diambilnya kebijakan ini berarti BRI Unit Porong harus melakukan pencadangan aktiva produktif sebesar 100\%. Percepatan Daftar Hitam dilakukan agar kondisi likuiditas, dalam hal ini nilai Non Performing Loan tidak terpengaruh, karena besarnya nilai kredit bermasalah tersebut tidak terhitung sebagai tunggakan dengan kategori Kurang Lancar (KL), Diragukan (D), dan Macet (M) yang mempengaruhi nilai Non Performing Loan. Hal ini tidak sesuai dengan pendapat Panji (2005) menyatakan "bahwa semakin tinggi Non Performing Loan suatu bank menunjukkan jumlah kredit bermasalah tesebut dalam jumlah yang relatif besar terhadap kredit yang disalurkan". Sehingga dapat disimpulkan bahwa dengan semakin besarnya nilai Non Performing Loan dapat diartikan tunggakan kredit yang terjadi semakin besar sehingga laba akan menurun. Dengan kata lain besar kecilnya Non Performing Loan akan berpengaruh terhadap laba yang selanjutnya akan berpengaruh terhadap likuiditas.

\section{KESIMPULAN}

Rata-rata Laba Usaha Unit di BRI Unit Porong mengalami penurunan yang sangat besar sampai menunjukkan angka minus atau mengalami penurunan yang sangat besar setelah adanya bencana lumpur panas lapindo. Sedangkan rata-rata Non Performing Loan (NPL) di BRI Unit Porong mengalami sedikit peningkatan sesudah bencana lumpur panas lapindo. Tetapi Non Performing Loan di BRI Unit Porong dalam kondisi sehat dengan nilai Non Performing Loan tertinggi sesudah bencana lumpur panas lapindo masih di bawah 5\% 
Peristiwa bencana lumpur lapindo menyebabkan meningkatnya kredit yang bermasalah, adanya kredit macet yang cukup besar mengakibatkan bank mengalami kehilangan pendapatan bunga dari kredit yang bermasalah tersebut. Hal ini menyebabkan Laba Usaha Unit di BRI Unit Porong periode sebelum dan sesudah bencana lumpur panas lapindo menunjukkan perbedaan yang signifikan.

Kredit yang bermasalah karena adanya bencana lumpur panas lapindo oleh pihak BRI Unit Porong dimasukkan dalam Daftar Hitam. Kebijakan ini diambil karena Porong masuk dalam kondisi force majeur atau bencana. Kredit bermasalah yang masuk Daftar Hitam tidak terhitungkan sebagai tunggakan. Hal ini menyebabkan tidak terdapat perbedaan yang signifikan pada Non Performing Loan (NPL) Bank Rakyat Indonesia Unit Porong periode sebelum dan sesudah bencana lumpur panas lapindo.

\section{DAFTAR PUSTAKA}

Firdaus, Rahmat. 2004. Manajemen Perkreditan Bank Umum. Bandung: Alfabeta.

Helfert, Erich. 1996. Teknik Analisa Keuangan (Petunjuk Praktis untuk Mengelola dan Mengukur Kinerja Perusahaan). Terjemahan oleh Herman Wibowo. 1997. Erlangga. Jakarta.

Kasmir.2002. Manajemen Perbankan. Jakarta: PT. Raja Grafindo Persada.

Modul PT. BRI (Persero). 2001. Kredit Umum Pedesaan (Kupedes).

Mulyono, Teguh Pudjo. 2001. Manajemen Perkreditan. Yogyakarta: BPFE.

Munawir, S. 2000. Analisa Laporan Keuangan. Yogyakarta: Liberty.

SE BI No. 7/3/DPNP. 2005. Tentang Penilaian Kualitas Aktiva Bank Umum.

SE Kanpus BRI No.:5.7-DIR/ADK/03/2005. Tentang Pemberlakuan Suku Bunga

Kupedes.

Santoso, Rudy Tri. 1997. Mengenal Dunia Perbankan. Yogyakarta: Andi.

Siamat, Dahlan. 2005. Manajemen Lembaga Keuangan. LPFE-UI. Jakarta.

Suhardjono. 2003. Manajemen Perkreditan Usaha Kecil dan Menengah. Yogyakarta: UPP AMP YKPN.

SE PT. BRI (Persero) Tbk Kantor Pusat NOSE : S. 13 -DIR/ADK/05/2005 Tentang Kualitas Aktiva Produktif dan Kualitas Agunan Yang Diambil Alih (AYDA).

Tunggal, Imam Sjahputra dkk. 2004. Peraturan Perundang-undangan Perbankan di Indonesia. Harvarindo. Jakarta.

Undang-Undang No. 7 tahun 1992 tentang Pokok-pokok Perbankan. 1993. Jakarta: Dharmapala.

Undang-Undang No. 10 tahun 1998 tentang Pokok-pokok Perbankan. 1999. Jakarta: Dharmapala. 